\title{
Assessment of Natural Resources and Local Community Participation in Nature-Based Tourism of Wehea Forest, East Kalimantan
}

\author{
Muli Edwin*, Iin Sumbada Sulistyorini, Jerlita Kadang Allo \\ Forestry of Study Program, High School of Agriculture (STIPER) East Kutai, \\ Jl. Sukarno-Hatta 01, Sangatta, Indonesia 75387
}

Received June 2, 2017/Accepted November 22, 2017

\begin{abstract}
Wehea forest is a highland of tropical rain forest on East Kutai Regency in East Kalimantan. The community especially Wehea ethnic in Nehas Liah Bing Village is well known for their traditional wisdom in utilizing the forest resources. Wehea Forest Area is a cluster of Maput and Pendreh land systems, and both land systems are irregular hilly regions that have steep to very steep slopes. Because of the uniqueness of biodiversity, landscapes, and traditional wisdom of Wehea ethnic the forest has been declared as forest reserve. This study aimed to assess the natural resources, culture, and participation local community as potential for nature based turism development. The result showed that the Wehea forest has biodiversity of flora dan fauna. Species of flora which are often founded are families of Dipterocarpaceae, Annonaceae, Lauraceae, etc. Fauna potentials are not less important and interesting than flora ones. There are several species which have endangered and protected status. The uniqueness of natural forest landscape really supports to various ecotourism activities. Wehea forest wealth also comes from local community presence. Their awareness is relatively high about Wehea forest existence, especially communities in Nehas Liah Bing. Dayak ethnic of Wehea has unique culture to be developed as tourist attraction. There are also other ethnics are Dayak kayan in Miau Baru Village and Java ethnic community in Makmur Jaya Village wich was once a transmigration village. Both communities in the village are familiar about the Wehea forest existence. Culture value diversity, awareness, and participation of local communities become strong capital to develop natural based turism and are expected to contribute to economic diversification region.
\end{abstract}

Keywords: traditional wisdom, Wehea, biodiversity, forest resources

*Correspondence author, email: muli.edwin@ stiperkutim.ac.id, ph.: +62-81347140335

\section{Introduction}

Growth rate of the total population and land conversion of forests have an influence on the development and economy of a region. Development in several regions including East Kalimantan is still dominated by two main sectors namely coal mining and oil palm plantations which are main stay for the improvement of the regional economy, while the nature tourism sector has not been maintained to serve as sources of region revenue. Bappeda Kaltim (2013) reported that East Kalimantan economy (without North Kalimantan) during 2001-2011 was dominated by the mining and industry sectors. Bappeda Kutim (2016) in general also claimed that the economy in East Kutai Regency was still dominated by the mining sector. Palm plantation area in East Kutai Regency in 2015 was amount of 406,467.47 ha and some districts became development centers of palm plantations and built 22 units factory of $\mathrm{CPO}$ (crude palm oil).

Hussien et al. (2010) stated that tourism sector provided a significant contribution to the economic development of Indonesia. Great cultural diversity of Indonesia is supported by its geographic position, where one-third of the world's tropical territory lies here as well as the length of its shore, supports the development of tourism sector. Santosa (2002) stated that tourism was categorized as the world's largest industry groups. Tourism has become a trending attention of international organizations, such as United Nation (UN), World Bank, and World Tourism Organization (WTO) where they have recognized that tourism is an integral part of human life, especially regarding the social and economic activities. Açiksöz et al. (2010) describes for a long time that tourism has been described as "clean industry" which does not have adverse effects on the environment compared to other industries and other business activities. Ecotourism is a concept that has contribution to the protection of nature that rely on natural resources or ecology to be offered to tourists.

Ecotourism has obtained global attention since it was officially coined in an international environmental conference held in Mexico in 1986. It has become a popular section of the tourism industry in many countries (Wang et al. 2014). Ecotourism is an important instrument used for contribution to preservation of the natural landscape and offers a solution to the poverty problem which is common in 
under-developed regions (Açiksöz et al. 2010). Development of ecotourism sector is certainly worth further encouraged, because of the challenge of fulfilling the promise of ecotourism definition of which is responsible travel to natural areas that conserves the environment and improves the welfare of local community (Zambrano et al. 2010). According Fandeli (2000) ecotourism based on conservation principle is an important principle in the vision of ecotourism, and all together between the community empowerment and the people's economy development can be the cornerstone of the ecotourism development.

Wehea forest has an area approximately of 38,000 ha located in Muara Wahau District, East Kutai Regency, East Kalimantan Province, about $450 \mathrm{~km}$ north of Samarinda. The legal status of de jure of Wehea forest is a forest production, but since 2002 there is no longer operational exploitation activities after the Forestry Department of Indonesia Republic revokes a concession license of PT Gruti III in the region. Therefore, since 2003 several private companies have applied for the conversion of forest areas into oil palm plantations or logging area (Falah 2011). Since that time, it has also occurred encroachment on forest areas to accelerate deforestation of Wehea because no guard region. Purwanto et al. (2015) has analyzed that the rate of deforestation of Borneo during 2003-2013 reached $77.01 \%$, whereas this area is expected in sustainable forest management must consider the environmental and socio-economic conditions of the community.

Fandeli (2000) stated the birth of ecotourism was a combination of environmental concerns and deforestation. Forests may serve as an ecotourism-based environment, as the Nature Conservation Areas like as national parks, forest parks, tourism nature parks, regional nature reserves (wildlife) and protected forests through ecotourism activities restricted, as well as production forest that serves as ecotourism. Then it is also described in the rules and regulations of the Republic of Indonesia relating to ecotourism, among others, Law Numbered 41 of 1999 on Forestry, which explains that the use of protected forest could be area utilization, environmental services and the collection of non-timber forest products. Utilization of environmental services at the forest preserve is a form of business that exploits the potential of environmental services, namely the natural scenery, fresh air and water without damaging the environment, and reduces its primary function. Then Government Regulation Numbered 34 of 2002 on Forest Management and Forest Management Planning, Forest Utilization and Forest Area, has explained that most of protected forest areas that have the beauty or uniqueness of the landscapes are developed as nature parks and can be licensed as business of services environment.

Through the traditional institutions of community (Adat Dayak Wehea) has issued a traditional decision about Wehea forest as Wehea Forest Preserve (Keldung Laas Wehea in Wehea language). In 2005 the government of East Kutai Regency has proposed changes in the function of Wehea forest into a protection forest. Wehea forest has a wealth of very many flora and fauna as well as the high steep topography and is in the upper of Mahakam river basin as a water catchment. Based on the results of potential survey conducted by Mulawarman University in collaboration with The Nature Conservancy (TNC), it is concluded that $70 \%$ of Wehea forest are still in good condition and has not been much affected by logging. Biodiversity potential of fauna in Wehea forest is very high, especially for a group of primates, mammals, and birds. Then the flora potential is also very diverse, ranging from the spesies of trees, orchids, fungi, liana, and other species (Falah 2011). The studies conducted by Sulistyorini (2010) stated that forest Wehea has a very unique and attractive natural potential, then there is also a local community namely "Dayak Wehea" who still upholds the values of local wisdom in utilization of forests including forest Wehea which is until now maintained and managed by the indigenous community of Wehea.

Indigenous and around communities are inseparable in the management of the forest area, so it is necessary to identify both their perception and participation of forest management. Sardjono (2004) explained that the participation of an active involvement in the party or outside in all decisions was related to the goals, objectives and activities, as well as in the implementation of the activity itself. Andrade and Rhodes (2012) stated that local community participation was very important in decisionmaking process and it was the only variable that was significantly related to the level of compliance with protected area polices. In general, the higher the level of participation is the higher the level of compliance. This has important implications for protected areas and the management should be a key strategy for ensuring the integrity of protected areas. Endter-Wada et al. (1998) stated that ecological data should be supplemented by scientific analysis of social factors as relevant keywords associated with a particular ecosystem. Analysis of social data should be included in a comprehensive manner in ecological studies. The research itself has aimed to probe the biogeographic potential especially vegetation, soil, and land system conditions of Wehea forest and the socio-economic conditions of local communities. So the useful information is expected in the management of forest ecosystem services, and it could serve as a model Wehea forest management in the future based on partnership with local communities. Li (2013) states that sustainable tourism is a political issue, as it concerns the distribution of resources, both now and in the future. The idea of community involvement as a basis of sustainable tourism is challenging since the communities are seldom similar in understanding sustainable tourism. WTO (1995) stated that tourism was considered as an essential activity to the life of nations because of its direct effects on the social, cultural, educational, and economic sectors of national societies and on their international relations. Zimmer and Grassmann (1996) claim that tourism boosts up economic activities through its multiplier effects and exploits local cultural and natural specialties in a positive way (Abdulla \& Mitra 2012).

\section{Methods}

The methodology applied in this research was public 


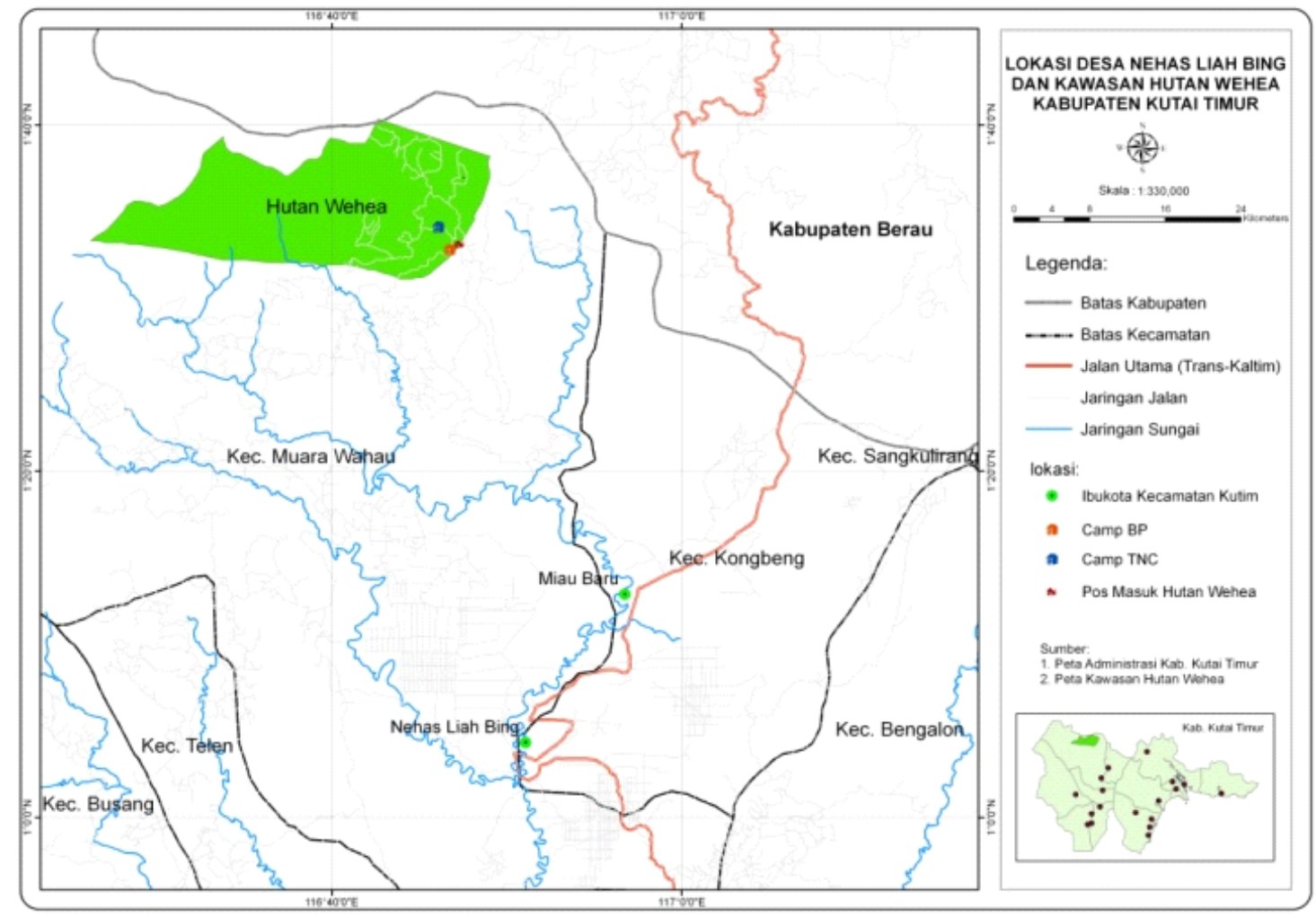

Figure 1 Map of Wehea forest on Muara Wahau subdistrict in East Kutai Regency.

perception and participation instrument which was easy to handle and use to measure the potential of nature tourism. The potential of the measured field consisted of potential vegetation, landscape condition with scoring system, and literature to other potential supporters, especially fauna as well as the socio-economic conditions, perceptions, and participation of local communities.

In this research there were three main studies, namely condition of vegetation, landscape for ecotourism, and perception-participation of local communities. The research was conducted at the near villages to Wehea forest (Figure 1) and they were Nehas Liah Bing Village in subdistrict of Muara Wahau, Miau Baru, and Makmur Jaya villages in Subdistrict Kongbeng. Collection of data related to socioeconomic consisted of perception, and participation, whereas community identity consisted of age, education, employment, livelihoods, and income level. Collected vegetation data of the structure of vegetation consisted of number of species, density, species dominance, diversity, and evenness. Then, the supporting data were also conducted through literature studies on regional geophysical conditions, fauna, art, and culture of local communities.

Vegetation analysis of this research is collection of data vegetation used in transect or line terraced method with total of plot area of 1.6 ha at 40 plots on two land systems, namely Maput (MPT) and Pendreh (PDH) in Wehea forest areas. Richard (1952) states that a single plot of 1.5 ha of most of tropical rain forest area is sufficient to represent stand. Nicholson (1965) also states that the plot sampling with an area ranging $0.6-1.5$ ha of north Borneo rainforest has already represented stand. According to Soerianegara and Indrawan (2002) the minimum area of plot sampling on species curve is 1.6 ha with provisions of $2 \times 2 \mathrm{~m}$ area for seedlings, $5 \times 5 \mathrm{~m}$ for saplings, $10 \times 10 \mathrm{~m}$ for poles, and $20 \times$ $20 \mathrm{~m}$ for trees. The size vegetation is based on a growth rate of seedling with height of less than $1.5 \mathrm{~m}$, sapling with height ranging from $1.5 \mathrm{~m}$, and diameter of $<10 \mathrm{~cm}$, poles with diameter at breast height ( $\mathrm{dbh}$ ) between $10-19 \mathrm{~cm}$, and trees with dbh of stems $>20 \mathrm{~cm}$. Analysis of vegetation data is conducted by calculating the dominance of species (important value of species), i.e. the sum of the density, frequency, and relative dominance are adopted from the formula of Curtis (1959). Dominance level for small vegetation or summed of Dominance Ratio (SDRn) was used the analysis formula analysis by Numata et al. (1958). The species diversity index $\left(\mathrm{H}^{\prime}\right)$ was calculation by using the Shannon-Wiener (1949) Formula. The H' value illustration the stability of veegetation.

Identification of potential landscape for ecoturism development was done by conducting field surveys in Wehea forest area. Potential of tourism attraction was founded in certain location with coordinate points marked by Global Positioning System (GPS) that will be the location of facility designed as ecotourism activities. Natural potential that can be developed for ecotourism in forest area are rivers, waterfalls, caves, and others. Landscape analysis was done using ranking models with scoring method based on the 
criteria used by Fandeli (2002). Valuation for each criteria which consists of five landscape elements (Table 1) was obtained from total value and tabulation according to the ranking. Each element was rated according to the level of beauty of these elements, and summed to determine the level of visual quality criteria, namely grades 19-33 (including class A high quality), grades $12-18$ (including class B medium quality), and grades $0-11$ (including class $\mathrm{C}$, low quality).

Assessment of perception and participation The assessment of perception and participation in this study was conducted using a survey with the direct interview method. Data analysis of respondent number to the communities perception was determined based on head number of households, and not population number in a village. Nehas Liah Bing Village was considered as a homogenous rural community which is relatively dominated by Dayak Wehea ethnic. Respondent number of the village was 25 out of 421 heads of households. Determining the level of community perception about Wehea forest areas can be known by making tabulation and descriptive analysis. The representation of criteria level of the respondents was estimated by using formula by Sevilla et al. (1993) is shown in Equation [1].

$\mathrm{n}=\frac{\mathrm{N}}{1+\mathrm{Ne}^{2}}$

note: $\mathrm{n}=$ number of respondents, $\mathrm{N}=$ population size (number of household), $\mathrm{e}=$ level of representation (0.2).

Assessment of the level participation of local communities in the implementation of conservation programs in Wehea forest based multiplication of index

Table 1 Criteria and score of landscape element

\begin{tabular}{|c|c|c|}
\hline $\begin{array}{l}\text { Landscape } \\
\text { element }\end{array}$ & Criteria & Score \\
\hline \multirow[t]{3}{*}{ Landform } & Undulating hills, foothills or flat valley floor or no traits attractive landscape & 1 \\
\hline & $\begin{array}{l}\text { Steep slopes, mountain cone or patterns of erosion by wind are attractive; or variations in the size, form } \\
\text { and land; or detail characteristics of dominant }\end{array}$ & 3 \\
\hline & $\begin{array}{l}\text { High vertical relief shown their rock outcrop or surface variation were amazing; formations erodible or } \\
\text { dominant characteristic is especially striking }\end{array}$ & 5 \\
\hline \multirow[t]{3}{*}{ Vegetation } & Little or no difference & 1 \\
\hline & Some species of vegetation but only 1,2 or 3 species of dominant & 3 \\
\hline & Many species and vegetation that attract, shown in patterns, textures and shapes & 5 \\
\hline \multirow[t]{3}{*}{ Water/river } & Water not available or there but not noticeable & 0 \\
\hline & Flowing with quiet but not a dominant & 3 \\
\hline & Clear, clean, flowing, rippling or any component of the dominant water & 5 \\
\hline \multirow[t]{3}{*}{ Color variation } & Variations smooth color and contrast, generally die & 1 \\
\hline & $\begin{array}{l}\text { There are many kinds of colors, there is a conflict the color of soil, rock and vegetation, but not the } \\
\text { dominant element of beauty }\end{array}$ & 3 \\
\hline & $\begin{array}{l}\text { The combination of broad range of colors or vibrant colors or opposition beautiful colors of the soil, } \\
\text { vegetation, water, etc. }\end{array}$ & 5 \\
\hline \multirow[t]{3}{*}{ Scenery } & Scenery nearby little or no effect on the overall landscape quality & 0 \\
\hline & Sights nearby enough to affect the quality of the scenery & 3 \\
\hline & Sights nearby greatly affect the quality of the scenery & 5 \\
\hline
\end{tabular}

Source: Fandeli (2002)

Table 2 Slope level on Wehea forest area

\begin{tabular}{clcc}
\hline Slope (\%) & Category & Large (ha) & Large (\%) \\
\hline $0-8$ & Flat & 5,008 & 13.2 \\
$8-15$ & Sloping & 6,269 & 16.5 \\
$15-25$ & Bit steep & 9,289 & 24.4 \\
$25-40$ & Steep & 10,742 & 28.3 \\
$>40$ & Very steep & 5,938 & 15.6 \\
\hline there is no data & & 754 & 2.0 \\
\hline & Total & 38,000 & \\
\hline
\end{tabular}

Source: Government of East Kutai Regency (2005) 
numbers of actors (who?), index numbers in terms of what (what?), and index numbers of how participation (how?) based of Empowerment Index principles with scale of 1-5 (Shubert 1996 in Irwanto 2006). The result of multiplication from the scale was used to determine the level of participation of local communities based index of the lowest value (1) to the highest value (125) by sharing as much as 5 categories namely very low (score of 1-25), low (scores of 26-50), medium (score of 51-75), high (score of 76-100), and very high (score of 101-125).

\section{Results and Discussion}

Wehea forest areas are economically less feasible anymore to silviculture activities as production forests because the potential of commercial species has been reduced. In some parts of the areas, there is still potential for commercial trees, but they are on steep and very steep slopes (Table 2), so technically it is very difficult to carry out harvesting activities. Since 2005 year, it has been formed an organization named Management Agency of Wehea Protected Forest or called as BP-HULIWA and Field Managing or Unit Petkuq Mehuey (PM) in Wehea language. Their task is to secure the area, to make arrangements of functionality, to conduct utilization and, to perform completion of the violations that occurred in forest areas Wehea (Government of East Kutai Regency 2005).

Research location on Wehea forest in Muara Wahau as shown in Figure 1 is adjacent with someborders, ex-PT Alas Helau in northern part, PT Gunung Gajah Abadi in eastern part, and PT Narkata Rimba in southern and western parts. The forest area is mostly a cluster of PDH and MPT land systems (Table 3). According to Subroto (2004) land system is defined as a map illustrating the grouping of a region based on various factors, including landscape, lithology, association soil, topography (slope), relief, climate, and other environmental phenomena that can be an indicator and determinant categories of land system.

Composition and dominance of species Based of analysis results, the number of species on all growth levels of vegetation (seedlings, saplings, poles, and trees) in land system of MPT have been founded as many as 1,621 trees with its density of 49,303 trees ha ${ }^{-1}$. In land system of PDH, it has been founded as many as 1,359 trees with its density of 35,989 trees $\mathrm{ha}^{-1}$, lower than species attendance on MPT land system. Differences in the species number were due to different habitat factors such as slope, altitude, soil characteristic, and species distribution. According Soerianegara and Indrawan (2002) topography factor may determine or influence on individuals, populations, and communities of vegetation. Besides topography factors, there are edaphic factors such as soil properties which also influence to species presence on both the land systems. Each species also has the different of tolerance limits which can grow or live in a particular environment.

The results of the inventory of trees with $\mathrm{dbh} \geq 20 \mathrm{~cm}$ showed that there were 217 trees $^{-1}{ }^{-1}$ in MPT land system and 171 trees ha $^{-1}$ in PDH land system. Inventory of poles with

Tabel 3 Characteristics of land system on Wehea forest area

\begin{tabular}{|c|c|c|c|}
\hline \multirow{2}{*}{ Land characteristics } & \multicolumn{3}{|c|}{ Land systems } \\
\hline & Pendreh (PDH) & Maput (MPT) & Teweh (TWH) \\
\hline Large (ha) & \pm 23.773 & \pm 17.921 & \pm 110 \\
\hline Slope $(\%)$ & $26->40$ & $0->40$ & $0-40$ \\
\hline & $50 \%$ steep & $95 \%$ slope & $95 \%$ slope with peaks \\
\hline Slope distribution & $\begin{array}{l}25 \% \text { very steep } \\
25 \% \text { extreme steep }\end{array}$ & $5 \%$ flood flat & slightly softer \\
\hline Relief (m) & $>300$ & 51300 & 1150 \\
\hline Altitude (mdpl) & $100-2000$ & $0-1500$ & $0-300$ \\
\hline Mineralogi & Quartz, Felsic & Felsic & mixture \\
\hline Rainfall (mm year ${ }^{-1}$ ) & $1800-4400$ & $1600-4400$ & $1600-4400$ \\
\hline Temperature $\left({ }^{\circ} \mathrm{C}\right)$ & $\begin{array}{l}\text { Min. }=12 \\
\text { Max. }=31\end{array}$ & $\begin{array}{l}\text { Min. }=15 \\
\text { Max. }=31\end{array}$ & $\begin{array}{l}\text { Min. }=22-23 \\
\text { Max. }=29-31\end{array}$ \\
\hline Litology & Sandstone, conglomerate & Sandstone, mudstone, marl & $\begin{array}{l}\text { Siltstone, sandstone, } \\
\text { mudstone }\end{array}$ \\
\hline Great group of soil & Hapludults and Dystropepts & Hapludults and Dystropepts & $\begin{array}{l}\text { Tropudults, Dystropepts, } \\
\text { and Plinthudults }\end{array}$ \\
\hline Land use type & $\begin{array}{l}\text { Protected forest, } \\
\text { preserve flora/fauna, } \\
\text { education/research }\end{array}$ & $\begin{array}{l}\text { Protected forest, } \\
\text { tourism forest, } \\
\text { plantation limited }\end{array}$ & $\begin{array}{l}\text { Farm, } \\
\text { livestock, } \\
\text { agroforestry }\end{array}$ \\
\hline
\end{tabular}

Source: Land system RePPProT (Regional Physical Planning Program for Transmigration Development) 1987

Table 4 Total of family, genera, and species at all level vegetation growth on Wehea forest area

\begin{tabular}{lccc}
\hline \multicolumn{1}{c}{ Land system } & Family & Genera & Species \\
\hline Maput (MPT) & 48 & 94 & 181 \\
Pendreh (PDH) & 36 & 75 & 151 \\
Merging both (MPT and PDH) & 53 & 105 & 238 \\
\hline
\end{tabular}


Tabel 5 Importance value index of vegetation of tree level on Wehea forest

\begin{tabular}{|c|c|c|c|}
\hline \multicolumn{2}{|c|}{ MPT land system } & \multicolumn{2}{|c|}{ PDH land system } \\
\hline Species name & Family & Species name & Family \\
\hline Syzygium sp. & Myrtaceae & Shorea sp. & Dipterocarpaceae \\
\hline Shorea sp. & Dipterocarpaceae & Syzygiumsp. & Myrtaceae \\
\hline Shorea laevis Ridl. & Dipterocarpaceae & Shorea leprosula Miq. & Dipterocarpaceae \\
\hline Shorea patoiensis & Dipterocarpaceae & Palaquium quercifolium & Sapotaceae \\
\hline P.S.Ashton & & Burck. & \\
\hline Shorea leprosula Miq. & Dipterocarpaceae & Shorea gybertisiana Burck. & Dipterocarpaceae \\
\hline Shorea assamica Dyer. & Dipterocarpaceae & Shorea laevis Ridl. & Dipterocarpaceae \\
\hline Shorea gibbosa Brandis. & Dipterocarpaceae & Durio dulcis Becc. & Bombacaceae \\
\hline Shorea parvifolia Dyer. & Dipterocarpaceae & Vatica rasssak (Korth.) Bl. & Dipterocarpaceae \\
\hline $\begin{array}{l}\text { Syzygium hirtum (Kort.) } \\
\text { Merr. }\end{array}$ & Myrtaceae & Pometia pinnata Forst. & Sapindaceae \\
\hline Shorea maxwelliana King. & Dipterocarpaceae & $\begin{array}{l}\text { Eusideroxylon zwageri } \mathrm{T} \text {. et } \\
\text { B. }\end{array}$ & Lauraceae \\
\hline Sindora walichii Graham. & Caesalpiniaceae & Shorea bracteolata Dyer. & Dipterocarpaceae \\
\hline Durio graffithii Bakh. & Bombacaceae & Litsea sp. & Lauraceae \\
\hline Durio oxleyanus Griff. & Bombacaceae & Nephelium sp. & Sapindaceae \\
\hline Сіппатотит sp. & Lauraceae & Dimocarpus longan Lour. & Sapindaceae \\
\hline $\begin{array}{l}\text { Syzygium zeylanicum } \\
\text { Smaich. }\end{array}$ & Myrtaceae & Dialium indum $\mathrm{L}$. & Caesalpiniaceae \\
\hline
\end{tabular}

Tabel 6 Sum of dominance ratio (SDRn) of vegetation of seedlings level on Wehea forest

\begin{tabular}{|c|c|c|c|}
\hline \multicolumn{2}{|c|}{ MPT land system } & \multicolumn{2}{|c|}{ PDH land system } \\
\hline Species name & Family & Species name & Family \\
\hline Syzygium sp. & Myrtaceae & Syzygium sp. & Myrtaceae \\
\hline Selaginela sp. & Selaginellaceae & Shorea gybertisiana Burck. & Dipterocarpaceae \\
\hline Palaquium quercifolium Burck. & Sapotaceae & Shorea leprosula Miq. & Dipterocarpaceae \\
\hline $\begin{array}{l}\text { Cinnamomum coriaceum } \\
\text { Cammerl. }\end{array}$ & Lauraceae & Shorea sp. & Dipterocarpaceae \\
\hline Schima wallichii (D.C.)Korth. & Theaceae & Baccaurea sp. & Euphorbiaceae \\
\hline Sarcotheca acuminata Hall. f. & Oxalidaceae & Sindora $\mathrm{sp}$. & Caesalpiniaceae \\
\hline Shorea leprosula Miq. & Dipterocarpaceae & Lansium sp. & Meliaceae \\
\hline Scleria sp. & Cyperaceae & $\begin{array}{l}\text { Lithocarpus gracilis (Korth.) } \\
\text { Soepadmo. }\end{array}$ & Fagaceae \\
\hline Syzygium hirtum (Kort.) Merr. & Myrtaceae & Gluta renghas $\mathrm{L}$. & Anacardiaceae \\
\hline Timonius borneensis Val. & Rubiaceae & $\begin{array}{l}\text { Monocarpia margina lis } \\
\text { (Scheff.) J. Sincl. }\end{array}$ & Annonaceae \\
\hline Actinodaphane sp. & Lauraceae & Shorea leavis Ridl. & Dipterocarpaceae \\
\hline Mezzetia sp. & Annonaceae & Xantophyllum excelcum Miq. & Polygalaceae \\
\hline Madhuca malaccensis H.J. Lam. & Sapotaceae & Madhuca palembanica Miq. & Sapotaceae \\
\hline Popowia hirta (BI.) Endl. & Annonaceae & Nephelium sp. & Sapindaceae \\
\hline Xantophyllum excelcum Miq. & Polygalaceae & Ficus ribes Reinw. & Moraceae \\
\hline
\end{tabular}

dbh between 10-19 $\mathrm{cm}$ showed that there were 433 trees $^{-1}$ in MPT land system and 650 trees $\mathrm{ha}^{-1}$ in PDH land system. Purwaningsih et al. (2008) stated that density of species of trees with DBH $>10 \mathrm{~cm}$ in East Kalimantan was 557 trees ha $^{-1}$ in Wanariset Samboja, 413 trees ha $^{-1}$ in Malinau (Yusuf 2003), 521 trees ha $^{-1}$ in Berau (Sisy \& Saridan 1999), and 445 trees ha $^{-1}$ in Bukit Bengkirai (Simbolon et al. 2005).

Species number of vegetation founded on MPT land system is more than that founded in the PDH land system (Table 4). The difference is caused by the difference in land characteristics especially topography, and PDH has steeper slope level than MPT. Species founded in the MPT land system are dominated mainly by family of Dipterocarpaceae, Annonaceae, Myrtaceae, Euphorbiaceae, Moraceae, Lauraceae, and Anacardiaceae. PDH land system is dominated mainly by Dipterocarpaceae, Annonaceae, Myrtaceae, Euphorbiaceae, Sapotaceae, and Lauraceae. Some spesies which are dominant based on Importance Value Index are Syzygium sp., Shorea sp., Hopea laevis Ridl.,
Shorea leprosula Miq., Palaquium quercifolium Burck., Shorea gybertisiana Burck., and others (Table 5).

Based on research of Arbain (2008) and Rudianur (2008), it was also founded some dominant families similar with this study, they are Dipterocarpaceae, Annonaceae, Myrtaceae, Euphorbiaceae, Anacardiaceae, Sapotaceae, and Lauraceae. Species of Shorea spp. from Dipterocarpaceae is the most dominant species. Then there are also several species of protected vegetation, and one of them is Eusideroxylon zwageri T. et. B. Vegetation composition is indicated by the species number shown at each stage level in sufficient number of various spesies. There are also still a lot of big size trees.

Spesies are largely a primary species that are in Wehea forest and there are also some other commercial spesies, especially from family of Dipterocarpaceae. The results of this study and the previous one have shown that spesies of vegetation in the area are still largely dominated by the primary spesies even though the area is never impaired 
with the exploitation of commercial species conducted by PT Gruti III since 1990 years ago. It also proves that the disturbance to vegetation in Wehea forest mainly on observations at the two land systems have never experienced severe disruption. Sidiyasa et al. (2006) stated that forest functions well where ecologically it can provide benefits to surrounding communities indirectly, for example, to avoid the danger of flooding and landslides, to provide clear river water, fresh-clean air, and many others. While economically, the communities can take forest products (non-timber products, including fruits) directly and continuously over long periods of time.

Diversity and evenness index of spesies Soegianto (1994) stated that species diversity is a characteristic level of community based biological organization which can be used to express the community structure. High species diversity indicates that a community has a high complexity and stability to keep themselves remained stable despite the disruption of its components. Existence of spesies of vegetation in a forest community can be measured on Species Diversity Index. Diversity of species itself is affected by the number of species and their distribution (Ludwig \& Reynolds 1988; Irwanto 2006). Analysis of the H' and Evenness Index (e) at both locations on land system (Figure 2) revealed that the index of diversity and evenness for seedling vegetation in both land systems are lower than vegetation level of trees, poles, and saplings. This happened because the individual number of seedling level is very large while spesies number is small. Species number and individuals number affects to diversity index. Soegianto (1994) stated that a community will be at the level of tree growth, and regeneration levels will have high species diversity if the community is composed by many species abundantly.

High species diversity in Wehea forest is a natural floristic

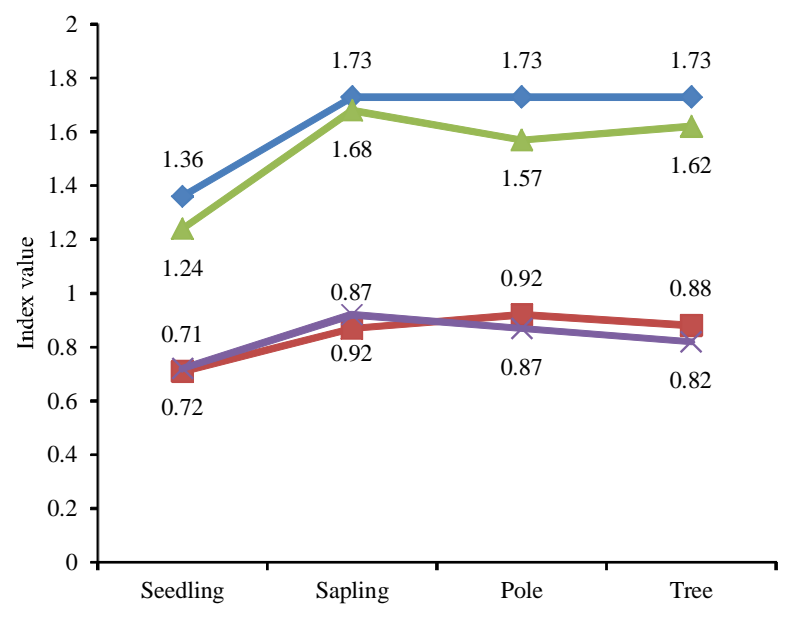

Figure 2 Diversity $\left(\mathrm{H}^{\prime}\right)$ and evenness (e) index of spesies on MPT (Maput) and PDH (Pendreh) Land System in Wehea forest. MPT $\left(\mathrm{H}^{\prime}\right)(-)$, MPT (e) (- - ), $\mathrm{PDH}\left(\mathrm{H}^{\prime}\right)(-), \mathrm{PDH}(\mathrm{e})(\underset{\sim}{\longleftarrow})$. richness that must be protected. The floristic richness as a source of germplasm can also be developed as a tourism destination in tropical forest. From many spesies of vegetation founded in Wehea forest, there are 21 species identified as having properties as medicinal plants such as Eurycoma longifolia (pasak bumi) in a form of shrub; Aquilaria malaccensis (aloes), Litsea sp. in a form of tree and others. From 21 species of medicinal plants which are known in Wehea forest, there are some spesies that have not been identified their benefits because of required separate studies related research on medicinal plants on Wehea forest. Diversity of medicinal plants could be the attractions object for turism, especially if they can be cultivated by local community, so it can add and expand the collection of medicinal plants and provide business opportunities for local community.

The study of traditional communities in developing countries shows how much they depend on the natural environment to get the traditional medicines and about $80 \%$ of the world population still rely on traditional medicines derived from thousands of plants (Indrawan et al. 2007). Selection of natural ingredients for traditional medicine based on research evidence states that every plant contains receptors, such as the chemical structure and hormone similar to human beings, and there is one study which proves that the leaves contain a substance present in the human head, while the substance contained in roots or twigs of plants is similar to the substances contained in the feet and hands of human (Utami 2008). This suggests that the use of traditional medicines from natural plants will thrive in the future. Meanwhile Wehea forest with rich flora of the tropical rainforest could be a good opportunity to bring tourists to the promotion of Wehea forest medicinal plants and medicinal plants cultivated by local communities.

People have been using herbal medicines for thousands of years. The advantages of this type of therapeutics include good availability, local cultural aspects, individual preferences, and increase of demand for natural and organic products (Carmona \& Pereira 2013). According Utami (2008) the advantages of traditional or herbal medicine are reside in a form of natural ingredients so that the side effects can be minimized. Now it is becoming a trend in lifestyle "back to nature", so that there are still many people who take advantage of variety natural ingredients for medication of mainly local communities around the forest. Moreira et al. (2013) stated that in the European Union, traditional herbal medicines are regarded as "acceptably safe, albeit not having a recognized level of efficacy fit into a special category of drugs or traditional herbal medicine products.

The landscape potential for natural tourism Ecotourism landscapes are germane to the overall success of the ecological conservation movement and upholding the indigenous value-system of the local communities, with numerous social, economic, and cultural benefits, and for future, studies on exploration ecotourism landscapes will be more conducted on developing nations (Adeniran \& Akinlabi 2014). General points of attractions of natural turism are found in an area or region by exploiting the potential such as 
rivers, beaches, springs, waterfalls, caves, forests, and so on, where each attractions needed to be developed further (Fandeli 2002). Assessment of the potential landscape can be used ranking models (scoring model), quantifies the aesthetic landscape elements like physical, biotic, and water quality, as well as other interesting elements. Each element has several parameters that are given a score of 1-5. Survey of landscape potential in Wehea forest areas were conducted at four selected locations. From four locations, there are two locations which have high category and two more medium category for the potential development of ecotourism based on the landscape condition (Table 7). The location choice was based on recommendations from the Wehea forest management units in the field. The four locations are namely "4625", "View Tower", "Giant Tree", and "Bat Waterfall".

\section{5}

Distance field to the location from camp of BP-HULIWA is about $4.625 \mathrm{~km}$ which can be reached by hiking trip in about 3 hours. This region has very steep sloves, so it has the potential for hiking. With high relief, the scenery can be viewed freely, making it very attractive to be used as natural tour activities such as tracking, hiking, and enjoying panorama. To travel to this location will also pass several rivers and there is one of the rivers which has reddish rocks and clear water.

\section{View Tower}

View tower is the supporting facility that can be used in ecotourism activities, one of the activities is to enjoy the natural beauty of the height location. Wehea forest has 2 locations of view towers which are located not far apart, about $1 \mathrm{~km}$. Access to these locations can be reached on walking with about 4 hours from BP-HULIWA camp. The activities that can be done from the view tower are enjoying interesting object, photography, bird watching, and research turism.

\section{Giant Trees}

The Giant tree of Shorea sp. is of one tree that is found with the largest size among other trees ever encountered by keeper or PM in Wehea forest area. The tree has a size buttres reaching 3-4 meters, diameter about $4 \mathrm{~m}$, and the distance from trail about $5 \mathrm{~m}$. On the track, there are still many other tree species that are large mainly from Dipterocarpaceae family, and species from other family. Species diversity of flora and fauna in this location are very abundant, so that it is very interesting to be developed as ecotourism or education turism area.
4 Bat Waterfalls

Bat waterfall is a location where there are some nest of bats that occupy small caves near the river. The rivers have the several small waterfalls and rivers. Their water is clear with rocky floor or small pebbles. The scenery of small waterfalls is very interesting because it is still natural, and there are still many natural vegetation with lush trees. On the track at this location, there are four waterfalls, each of which has various height of $7-10 \mathrm{~m}$.

Besides floristic potential and landscape, there are also potentials of fauna which are not less important and interesting. During the rainy season there are found a lot of forest leech (Haemadipsa sp.). There are two spesies of leeches ever encountered, namely brown leech (Haemadipsa zeylanica) and tiger leech (Haemadipsa picta), which inhabit in the forest floor and undergrowth. The existence of leeches can provide a special attraction, because it is useful in terms of health. Kendall (2012) stated that rainforests around the world are facing increasing pressure from deforestation, so that $\mathrm{H}$. picta and $\mathrm{H}$. zeylanica decline abundantly. No more leech is found in oil palm plantations.

In Wehea forest, there is also endangered fauna or protected fauna such as hornbill (Hornbill sp.), lemur (Tragulus Nafu), orangutan (Pongo pygmaeus), monkey (Presbytis sp.), jungle fowl (Lophura inornata), wild boar (Susbarbatus), tiger bough (Neofelis diardi borneensis), and others (BP Huliwa 2005). Other researcher, Loken (2016) founded Miller's Grizzled langur (Presbytis hosei canicrus) population in Wehea forest may become endangered. The potential of high biodiversity in Wehea forest should be used for the purpose of nature turism with the involvement of local communities. The turism is expected to be education and research, which has double functions namely environmental education and economic improvement of local communities.

Perception and participation community Forest as an ecosystem, is not just a collection of vegetation and wildlife. In some forests, the human component in this community has become an integral part of the forest, and even help determine the existence of existing ecosystems because in meeting their needs, they utilize the forest or forest land (Sardjono 1998). Furthermore Simpoha (1998) stated that the local community can consist of: indigenous tribal community, indigenous community, and mix-communities (including migrant communities). Each development program including forest conservation program needs to adapt to local conditions and involve local communities in every stage. The elements of

Table 7 Results of landscape potential assessment for ecotourism in four locations at Wehea forest

\begin{tabular}{|c|c|c|c|c|}
\hline \multirow{2}{*}{ Landscape elements } & \multicolumn{4}{|c|}{ Scores for the four locations } \\
\hline & 4625 & Viewing Tower & Giant Tree & Bat Waterfall \\
\hline Landform & 5 & 3 & 1 & 1 \\
\hline Vegetation & 5 & 5 & 5 & 5 \\
\hline Water/river & 5 & 0 & 5 & 5 \\
\hline Colour & 5 & 5 & 3 & 5 \\
\hline Scenery & 3 & 3 & 3 & 3 \\
\hline Score total & 23 & 16 & 17 & 19 \\
\hline Category & Class A (high) & Class B (medium) & Class B (medium) & Class A (high) \\
\hline
\end{tabular}


the local communities on the other hand is part of the whole local communities, so that it cannot be separated between these elements (Margiyono 1999). Forest conservation program that includes the participation of local communities should be able to cultivate the support and caring attitude of communities toward the ultimate goal of the program. Participation of local communities in conservation or preservation of the forest will grow experience and a sense of belonging. Experience and sense of belonging that can be initiated from the communities' knowledge of the existence of the development object.

Based on the research, it is known that not all of local communities aware of the existence Wehea forest, especially communities in Miau Baru and Makmur Jaya villages. the communities of Miau Baru Village know about the existence Wehea forest in amount of 50\%, and those of Makmur Jaya Village know it about $16.67 \%$, while communities in Nehas Liah Bing have already been very familiar about the existence of Wehea forest, as seen from Table 8. Villagers of Nehas Liah Bing are majority from Wehea tribe who have long known the existence of Wehea forest, they historically and culturally have a strong relationship with the surrounding forest. Their active community involvement
Nehas Liah Bing in preserving and protecting Wehea forest was proved by obtaining Kalpataru award from Government of Indonesia Republic in 2009 for their effort in preserving the Wehea forest.

Lack of knowledge and understanding of most community in the Miau Baru and Makmur Jaya villages is caused by several reasons, such as lack of socialization and counseling about the existence, and function of the Wehea forest and lack of government presence or Wehea forest, management to dialogue with local communities about the existence and functions of Wehea forest. In general, the community in both villages are not actively involved in the grounds that they have been deliberately excluded by parties who have authority over Wehea forest management. Table 9 presents the involvement of local communities in all groups of respondents on the function and intensive participation in Wehea forest conservation efforts.

After assessing participation, then determining perception community of ecotourism development was conducted (Table 10), especially community in Nehas Liah Bing Village with respondent number of 25 people out of 421 households. In the ecotourism development on Wehea forest should pay attention and be able to maintain the forests

Table 8 Knowledge of local communities about Wehea forest

\begin{tabular}{|c|c|c|c|c|c|c|}
\hline \multirow{3}{*}{$\begin{array}{l}\text { Level of } \\
\text { knowledge } \\
\text { about the } \\
\text { Wehea forest }\end{array}$} & \multicolumn{6}{|c|}{ Vilagge } \\
\hline & \multicolumn{2}{|c|}{ Miau Baru } & \multicolumn{2}{|c|}{ Makmur Jaya } & \multicolumn{2}{|c|}{ Nehas Liah Bing } \\
\hline & $\mathrm{F}$ & $\%$ & $\mathrm{~F}$ & $\%$ & $\mathrm{~F}$ & $\%$ \\
\hline Knowing & 15 & 50.00 & 5 & 16.67 & 30 & 100.00 \\
\hline Do not know & 15 & 50.00 & 25 & 83.33 & - & 0 \\
\hline Total & 30 & 100.00 & 30 & 100.00 & 30 & 100.00 \\
\hline
\end{tabular}

$\mathrm{F}=$ Frequency

Table 9 Community involvement based the intensity of participation

\begin{tabular}{lcccccc}
\hline Community involvement/village & \multicolumn{2}{c}{ Miau Baru } & \multicolumn{2}{c}{ Makmur Jaya } & \multicolumn{2}{c}{ Nehas Liah Bing } \\
\cline { 2 - 7 } & F & $\%$ & F & $\%$ & F & $\%$ \\
\hline Information & - & - & - & - & 22 & 73.33 \\
Consultation & - & - & - & - & 3 & 10.00 \\
Decision maker & - & - & - & - & 1 & 3.33 \\
Action initiatives & - & - & - & - & - & 0.00 \\
Supervision & - & - & - & - & 4 & 13.34 \\
\hline Number of respondents participate & 0 & 0.00 & 0 & 0.00 & 30 & 100.00 \\
\hline Number of respondents did not & 30 & 100.00 & 30 & 100.00 & - & 0.00 \\
Participate & & & & & & \\
\hline Total &
\end{tabular}

Table 10 Respondents perception to the ecotourism development in Wehea forest

\begin{tabular}{|c|c|c|c|c|}
\hline \multirow{2}{*}{ Ilustration } & \multicolumn{4}{|c|}{ Respondents } \\
\hline & Agree & $\%$ & Disagree & $\%$ \\
\hline Understanding of ecotourism & 17 & 68 & 8 & 32 \\
\hline $\begin{array}{l}\text { Opinions on the ecotourism } \\
\text { development plan }\end{array}$ & 19 & 76 & 6 & 14 \\
\hline $\begin{array}{l}\text { Opinions of the visitors who } \\
\text { came to the Wehea forest }\end{array}$ & 21 & 84 & 4 & 16 \\
\hline $\begin{array}{l}\text { Community involvement in } \\
\text { forest management }\end{array}$ & 22 & 88 & 3 & 12 \\
\hline
\end{tabular}


condition in a sustainable way. It is the community of Wehea including communities upstream (inland) is quite aware of the forests importance, because the condition lately where frequent floods and the impact much felt by people living on the edges of rivers. From the fact like this is expected to be a very useful input for the management and the government in preserve and managing Wehea forest. Based on the results of questionnaire it can also be deduced some suggestions from the community on Wehea forest management, namely: increase community participation in management and development ecotourism in Wehea forest, increase roads or means of transport, and improving education and skills such as training, counseling, and guidance to the community.

Based on the survey in the community, it can be seen that the availability of local labor for particular ecotourism does not need to look outside the region because the villages surrounding the forest of Wehea provide considerable potential labor force to support actively the local government and Wehea forest management to conduct training to get the skills of the local labor about ecotourism. Most community of Wehea still do farming for their daily needs, if the natural and cultural tourism can be developed more advanced there, the certain sector can be relied upon to increase the community's economy. Income levels of the community especially in Nehas Liah Bing Village is still low. With the ecotourism activities, besides the people do farming they also could have the opportunity to effort through handicrafts, art, and others. So ecotourism activities are expected to help improve the welfare and income of local communities.

Until now there are still events or festivals that are conducted by Wehea indigenous community who live scattered streams in Wehea and Telen rivers. One of them is the Feast of Rice (Lom Plai), Lom Plai in perspective Wehea community is a series of ritual for homage in order to maintain the sanctity of rice which is believed that it can save the entire community of famine disaster. Culture and arts community has the potential to provide cultural and evironmental experiences for tourists who visit the community. Iswandono et al. (2015) stated that the goverment should implement sustainable forest management by involving local communities as subjects who participated actively in managing the forest. Active involvement of local community must be based on existing local conservation values, norms, and tradition in forest mangement for ensuring sustainability of forest resources in the long run. According to Fandeli and Mukhlison (2000) the principles of ecotourism development could go well if there are culture preservation of forest communities, conservation, community participation and economic improvement of local community. Pratiwi (2006) stated that there are many factors affecting the success or failure of ecotourism development. One of the factors is the participation of local communities. Several communities had been indicated that they could still receive "nominal" benefits from their involvement in ecotourism development no matter what the level of participation in which they were involved.

\section{Conclusion}

Wehea forest area has a high potential to be developed as a natural tourism destination. Diversity of flora, fauna, and uniqueness of the natural forest landscape really support to the ecotourism development mainly for education and research. To ensure the sustainability of forests Wehea, the involvement of local community especially native Wehea community should receive serious attention from the government. Culture and tradition of local communities can be combined with the natural potential of Wehea forest in order to develop a tourism destination which is expected to increase the economy of communities around forest area.

\section{Acknowledgements}

The authors would like to deliver thanks and appreciations to the Indigenous Chairman of Wehea tribe $\mathrm{Mr}$ Ledjie Taq and Petkuq Mehuey (PM). Gratitute is also given to the Environment Agency of East Kutai Regency which has a lot of help in the completion of this study.

\section{References}

Abdulla AM, Mitra S. 2012. A methodology for assessing tourism potential: Case study Murshidabad District, West Bengal, India. International Journal of Scientific and Research Publications 2(9).

Açiksöz S, Görmüs S, Karadeniz N. 2010. Determination of ecotourism potential in national parks: Kure Mountains National Park, Kastamonu-Bartin, Turkey. African Journal of Agricultural Research 5(8):589-599.

Adeniran AJ, Akinlabi FJ. 2014. Ecoturism landscapes: An editorial. American Journal of Tourism Management 3(1A). https://doi.org/10.5751/ES-05216-170414.

Andrade GSM, Rhodes JR. 2012. Protected areas and local communities: An inevitable partnership toward successful conservation strategies? Ecology and Society 17(4):14. https://doi.org/10.5751/ES-05216-170414.

Arbain. 2008. Keanekaragaman floristik sub daerah aliran sungai sekung di hutan lindung Wehea Kecamatan Muara Wahau, Kabupaten Kutai Timur [undergraduated thesis]. Sangatta: Sekolah Tinggi Ilmu Pertanian Kutai Timur.

[BAPPEDA KALTIM] Badan Perencanaan Pembangunan Daerah, Provinsi Kalimantan Timur. 2013. East Kalimantan Vision 2030: Equitable and Sustainable Green Growth. Samarinda: Badan Perencanaan Pembangunan Daerah, Provinsi Kalimantan Timur.

[BAPPEDA KUTIM] Badan Perencanaan Pembangunan Daerah, Provinsi Kalimantan Timur. 2016. Rencana Pembangunan Jangka Menengah Daerah Kabupaten Kutai Timur 2016-2021. Sangatta: Badan Perencanaan Pembangunan Daerah, Kabupaten Kalimantan Timur.

Carmona F, Pereira AMS. 2013. Herbal medicines: Old and new concepts, truthsand misunderstandings. Brazilian Journal of Pharmacognosy 23(2):379-385. https://doi.org/10.1590/S0102-695X2013005000018. 
Curtis JT. 1959. The Vegetation of Wisconsin. Madison: University of Wisconsin Press.

Endter-Wada J, Blahna D, Karnnich R, Brunson M. 1998. A framework for understanding social science contribution to ecosystem management. Ecological Applications. Ecological Society of Amerika. Pp. 891-904.

Falah F. 2011. Proses Kebijakan dalam Upaya Perlindungan Hak Masyarakat Lokal atas Sumberdaya Hutan Wehea. Prosiding Hasil-Hasil Penelitian BPTKSDA. Kementrian Kehutanan, Badan Penelitian dan Pengembangan Kehutanan, Pusat Penelitian dan Pengembangan Konservasi dan Rehabilitasi. Balikpapan, 3 November 2011. Pp 177-188.

Fandeli Ch. 2000. Pengertian dan Konsep Dasar Ekowisata dalam Pengusahaan Ekowisata. Yogyakarta: Fakultas Kehutanan Universitas Gadjah Mada.

Fandeli Ch, Mukhlison. 2000. Pengusahaan Ekowisata. Yogyakarta: Fakultas Kehutanan Universitas Gadjah Mada dan Unit Konservasi Sumberdaya Alam Daerah Istimewa Yogyakarta.

Fandeli Ch. 2002. Perencanaan Kepariwisataan Alam. Yogyakarta: Fakultas Kehutanan Universitas Gadjah Mada.

Government of East Kutai Regency. 2005. Proposed: Function Changes of Forest Area in HPH Ex Gruti III as Wehea Forest Protected Areas "Long Skung Metgueen" in East Kutai. Kutai: Goverment of East Kutai Regency.

Hussien AS, Widagdo U, Asriwulan Y. 2010. The application of e-turism in small and medium-scale turism in Indonesia: A strategic management view. Journal of Indonesian Economy and Business 25(2):190-200.

Kendall A. 2012. The effect of rainforest modification on two species of South-East Asian terrestrial leeches, Haemadipsa zeylanica and Haemadipsa picta [thesis]. London: Master of Science of Imperial College London and the Diploma of Imperial College.

Li J. 2013. Sustainable ecotourism established on local communities and its assessment system in Costa Rica. Journal of Environmental Protection 4:61-66. https://doi.org/10.4236/jep.2013.41006.

Loken B. 2016. Conservation of Charismatic Endangered Species in Wehea Forest, Borneo: Interplay of Ecological and Social Factors in a Community-Based Conservation Project. School of Resource and Environmental Management, Faculty of Environment. Simon Fraser University, Spring.

Ludwig JA, Reynolds JF. 1988. Statistical Ecology: A Primer of Methods and Computing. New York: Wiley Press.

Indrawan M, Primack RB, Supriatna J. 2007. Biologi
Konservasi. Jakarta: Yayasan Obor Indonesia, Conservation International-Indonesia, Pusat Informasi Lingkungan Indonesia. Yayasan WWF Indonesia, Yayasan Bina Sains Hayati Indonesia.

Irwanto. 2006. Analisis struktur dan komposisi vegetasi untuk pengelolaan kawasan hutan lindung Pulau Marsegu, Kabupaten Seram Bagian Barat, Provinsi Maluku [thesis]. Yogyakarta: Program Studi Ilmu Kehutanan Universitas Gadjah Mada.

Iswandono E, Zuhud EAM, Hikmat A, Kosmaryandi, N. 2015. Integrating local culture into forest conservation: A case study of the manggarai tribe in Ruteng Mountains, Indonesia. Jurnal Manajemen Hutan Tropika 21(2):55-64

Margiyono. 1999. Studi Tentang Partisipasi Masyarakat Lokal Dalam Pembangunan Pedesaan. Ujung Pandang: Program Pascasarjana Universitas Hasanuddin.

Moreira DdeL, Teixeira SS, Monteiro MHD, De-Oliveira AC AX, Paumgartten FJR. 2013. Traditional use and safety of herbal medicines. Brazilian Journal of Pharmacognosy 24(2014):248-257. https://doi.org/10.1016/j.bjp.2014. 03.006 .

Numata I, Enjoji S, Urabe Y, Shoji H. 1958. Anthracnose of Calendula officinalis (new disease) (abstract in Japanese). Annals of the Phytopathological Society of Japan 23:21.

Odum EP. 1998. Dasar-dasar Ekologi. Samingan T, Srigandono B, translator. Edisi Ketiga. Yogyakarta. Universitas Gadjah Mada Press.

Pratiwi S. 2006. Local community participation in ecoturism development: A critical analysis of selected published literature. Jurnal Manajemen Hutan Tropika 12(2):69-77.

Purwaningsih T, Partomihargjo RY, Abdulhadi R, Riswan S. 2008. Froristics and structure of a lowland dipterocarp forest at Wanariset Samboja, East Kalimantan, Indonesia. A Jounal on Taxonomic Botany, Plant Sociology and Ecology, REINWARDTIA 12(4):261-337.

Purwanto J, Rusolono T, Prasetyo LB. 2015. Spatial model of deforestation in Kalimantan from 2000 to 2013. Jurnal Manajemen Hutan Tropika 21(3):110-118. https://doi.org/10.7226/jtfm.21.3.110

RePPProT. 1987. Review of Phase I Result East and South Kalimantan. RePPProT (Regional Physical Planning Program for Transmigration Development). Jakarta: Deptrans.

Rudianur. 2008. Analisis vegetasi pada ketinggian tempat yang berbeda di hutan lindung Wehea Kecamatan Muara Wahau, Kabupaten Kutai Timur [undergraduated thesis]. Sengata: Sekolah Tinggi Ilmu Pertanian Kutai Timur. 
Santosa SP. 2002. Pengembangan pariwisata Indonesia. http://kolom.pacific.net.id/ind/ setyanto_p._santosa/ artikel_setyanto_p._santosa/pengmbangan__pariwisata_ _indonesia.html. [08 April 2015].

Sardjono MA. 1998. Interdependensi Sosial-Ekonomi Masyarakat Dengan Pembangunan Kehutanan dan Tekanannya Terhadap Sumberdaya Hutan di Kalimantan Timur. Laporan Penelitian. Kerja sama Penelitian Antara Balai Penelitian Kehutanan dan Fakultas Kehutanan Universitas Mulawarman, Samarinda.

Sardjono MA. 2004. Mosaik, Sosiologis Kehutanan: Masyarakat Lokal, Politik dan Kelestarian Sumberdaya. Cetakan Pertama. Jogyakarta: DEBUT Press.

Sevilla CG, Tuwu A, Syah A. 1993. Pengantar Metode Penelitian. Jakarta: Universitas Indonesia Press.

Shannon CE, Wiener W. 1949. The Mathematical Theory of Communication. Urbana: University Illinois Press IL.

Simpoha JM. 1998. Masalah pengakuan formal atas sistem pengelolaan hutan berbasis masyarakat di luar Jawa. Duta Rimba 213/XXII.

Sidiyasa K, Zakaria, Iwan R. 2006. Hutan Desa Setulang dan Sengayan Malinau, Kalimantan Timur: Potensi dan Identifikasi Langkah-Langkah Perlindungan dalam Rangka Pengelolaannya Secara Lestari. Bogor: Center for International Forestry Research.

Soerianegara J, Indrawan A. 2002. Ekologi Hutan Indonesia. Bogor: Fakultas Kehutanan Institut Pertanian Bogor.
Subbroto. 2004. Geomorfologi dan Analisis Landscape. Samarinda: Fajar Gemilang.

Soegianto A. 1994. Ekologi Kuantitatif. Metode Analisis Populasi dan Komunitas. Surabaya: Usaha Nasional.

Sulistyorini IS. 2010. Analisis pengembangan potensi ekowisata di kawasan hutan Wehea Kecamatan Muara Wahau Kabupaten Kutai Timur. Jurnal Kehutanan Tropika Humida 3(1):54-62.

Utami P. 2008. Buku Pintar "Tanaman Obat" 431 Jenis Tanaman Penggempur Aneka Penyakit. Jakarta: Agromedia.

Wang L, Zhong L, Zhang Y, Zhou B. 2014. Ecoturism environmental protection measures and their effects on protected areas in China. Sustainability 6:6781-6798. https://doi.org/10.3390/su6106781.

WTO. 1995. Technical Manual, "Collection of Tourism Expenditure Statistics", World Tourism Organization [web: wikipedia.org/wiki/Tourism].

Zambrano A, Angelica M, Broadbent EN, Durham WH. 2010. Social and environmental effects of ecotourism in the Osa Peninsula of Costa Rica: The Lapa Rios case. Journal of Ecotourism 9(1):62-83. https://doi.org/ $10.1080 / 14724040902953076$

Zimmer P, Grassmann S. 1996. Evaluating a territories touristic potential, LEADER Seminar in Sierra de Gata. http://ec.europa.eu/agriculture/rur/leader2/ruralen/biblio/touris/metho.pdf. [5 April 2017] 